\title{
Pengendalian dan Peningkatan Kualitas Produk Deo Go! Potato Menggunakan Metode Six Sigma di PT. Siantar Top, Tbk.
}

\author{
Luluk Mukarromah, Haryono, dan Diaz Fitra Aksioma \\ Departemen Statistika, Fakultas MIPA, Institut Teknologi Sepuluh Nopember (ITS) \\ e-mail: haryono@statistika.its.ac.id
}

\begin{abstract}
Abstrak-Salah satu produk unggulan PT. Siantar Top, Tbk pada kategori biskuit adalah Deo Go! Potato. Terdapat empat karakteristik kualitas yang sangat penting untuk dikendalikan supaya hasil produksi biskuit sesuai standar yang ditetapkan di Work Order (WO) perusahaan yaitu berat, diameter horizontal, diameter vertikal, dan ketebalan. Ukuran standar per 5 pes biskuit untuk berat antara 9,5-10,5 gram, diameter antara 54-56 $\mathrm{mm}$, dan tebal antara 5,5-6,5 mm. Perusahaan mempunyai target hasil proses produksi yang defect sebesar $1 \%$ per bulan. Pada proses produksi selama bulan Februari sampai Maret 2017 menghasilkan defect sebesar $5,45 \%$, sehingga terdapat gap sebesar 3,45\%. Pendekatan Six Sigma dapat digunakan untuk mengurangi persentase cacat dalam produksi. Penerapan Six Sigma diawali dari fase define, yaitu membuat goal statement, diagram SIPOC, dan histogram. Histogram menunjukkan bahwa proses produksi menghasilkan produk yang tidak sesuai spesifikasi. Pada fase measure melakukan pengukuran dan menghitung jumlah cacat (defect) untuk mengetahui nilai DPMO dan tingkat sigma. Nilai tingkat sigma proses produksi saat ini sebesar 3,71 sigma. Selain itu, hasil Gauge $R \& R$ tipe 1 menunjukkan bahwa alat ukur yang digunakan sudah baik. Sementara itu, pada fase analyze menunjukkan bahwa rata-rata proses tidak terkendali secara statistik. Jenis defect terbanyak yaitu tebal dan diameter horizontal tidak standar. Dari tabel FMEA diketahui penyebab potensial karena setting temperatur oven tidak tepat dan varian pemberian air saat proses mixing adonan, sehingga diberikan beberapa rekomendasi pada pihak perusahaan untuk perbaikan proses produksi.
\end{abstract}

Kata Kunci-Deo Go! Potato, DMAIC, Six Sigma.

\section{PENDAHULUAN}

$\mathrm{S}_{\mathrm{b}}^{\mathrm{L}}$ IANTAR Top, Tbk merupakan perusahaan yang menekuni bidang produksi makanan ringan seperti crackers, mie, dan biskuit. Konsumen PT. Siantar Top, Tbk meliputi berbagai kalangan usia, sehingga perusahaan dihadapkan pada tantangan yang cukup berat yaitu semakin meningkatnya tuntutan konsumen terhadap kualitas yang dihasilkan, juga diperkuat oleh tekanan persaingan dari perusahaan-perusahaan yang menawarkan produk sejenis. Salah satu produk unggulan PT. Siantar Top, Tbk pada kategori biskuit adalah Deo Go! Potato.

Pada proses produksi Deo Go! Potato dijumpai lebih dari satu karakteristik kualitas yang saling berhubungan yaitu berat, diameter horizontal, diameter vertikal, dan ketebalan. Pengukuran empat karakteristik kualitas tersebut dilakukan oleh operator QC menggunakan timbangan digital dan sketmat. Intruksi di Work Order (WO) untuk standar per 5 pcs biskuit yaitu berat antara 9,5-10,5 gram, diameter horizontal dan vertikal yaitu antara 54-56 mm, serta tebal biskuit antara 5,5-6,5 mm. Permasalahan yang sering terjadi dari kegiatan inspeksi adalah ditemukannya hasil proses yang tidak sesuai standar (defect). PT. Siantar Top, Tbk mempunyai visi yaitu menjadi perusahaan terkemuka yang terus tumbuh dan berkembang untuk memberikan jaminan mutu, sehingga persentase defect harus dikurangi menjadi dibawah $1 \%$ per bulan.

Pengontrolan beberapa karakteristik kualitas secara bersamaan menggunakan peta kendali MEWMA. Sebelumnya [1] telah melakukan penelitian dengan menerapkan diagram kontrol MEWMA untuk memonitor mean proses produksi di PT. Coca-Cola Bottling Indonesia Jawa Timur dan didapatkan hasil bahwa mean proses dalam keadaan yang tidak terkendali. Penyebabnya berasal dari faktor manusia, mesin, metode, material, dan lingkungan.

Saat ini, metode peningkatan kualitas produk yang sedang berkembang adalah Six Sigma. Six Sigma juga dapat dipandang sebagai pengendalian proses produksi yang berfokus pada tindakan-tindakan perbaikan [2]. Didalam penerapan Six Sigma terdapat lima langkah yang disebut DMAIC yaitu define (merumuskan), analyze (menganalisis), improve (meningkatkan/ memperbaiki), dan control (mengendalikan) yang menggabungkan beberapa perangkat statistik. Penelitian dengan metode Six Sigma pernah dilakukan oleh [3] untuk perbaikan proses produksi casing pompa di PT. Zenith Allmart Precisindo yang menunjukkan nilai DPMO sebesar 7.650,81 dan perusahaan berada pada level 3,925 sigma. Penerapan metode ini diharapkan dapat mengurangi jumlah produk defect yang dihasilkan dan perusahaan dapat melakukan peningkatan kualitas produk.

\section{TINJAUAN PUSTAKA}

\section{A. Six Sigma}

Six Sigma merupakan suatu level dari kinerja proses yang sama dengan memproduksi 3,4 produk cacat dalam 1 juta produk. Model umumnya yaitu Define-Measure-AnalyzeImprove-Control (DMAIC) [4].

1) Define

Pada fase define akan mendefinisikan kompleksitas masalah dengan membuat pernyataan tujuan (goal statement) dari proyek Six Sigma dan melalui histogram, kemudian menentukan karakteristik kualitas berdasarkan kebutuhan 
konsumen (voice of customer), serta membuat diagram SIPOC untuk menggambarkan informasi mengenai supplier, input, process, output, dan customer yang terlibat dalam proses produksi [5].

\section{2) Measure}

Kegiatan awal pada fase measure adalah mengumpulkan data karakteristik kualitas untuk menghitung nilai DPMO (Defect Per Million Opportunities). Dari nilai DPMO dikonversikan ke nilai sigma yang bertujuan untuk mengukur kinerja perusahaan saat ini pada tingkat proses produksi yang kemudian ditetapkan sebagai baseline kinerja pada awal proyek Six Sigma [5]. Adapun persamaan yang digunakan untuk menghitung tingkat sigma adalah sebagai berikut [6]:

$$
\begin{gathered}
\text { Tingkat Sigma }=Z\left(\frac{1.000 .000-D P M O}{1.000 .000}\right)+1,5 \\
\text { dengan } \quad D P M O=D P O \times 1.000 .000 \\
D P O=\frac{\text { jumlah produk cacat }}{\text { banyaknya jenis cacat } \times \text { jumlah unit yang diproduksi }}
\end{gathered}
$$

Apabila tingkat sigma sebesar 6 sigma berarti perusahaan hanya menghasilkan 3,4 produk cacat dalam satu juta produk atau $99,99966 \%$ produk bebas dari cacat [7].

Selain itu perlu dilakukan pengujian terhadap sistem pengukuran (measurement system) yang digunakan agar data hasil pengukuran dapat dinyatakan valid. Pada penelitian ini, measurement system berupa alat ukur yang digunakan oleh satu orang operator dan untuk melakukan analisisnya dapat menggunakan Gauge $R \& R$ tipe 1. Dari Gauge $R \& R$ tipe 1 diperoleh \% variasi repeatability. Menurut [8] petunjuk penerimaan sistem pengukuran sebagai berikut, jika \% variasi repeatability lebih besar dari $30 \%$ maka sistem pengukuran tidak dapat diterima dan harus dilakukan perbaikan. Saat $\%$ variasi repeatability berada di antara $10 \%$ sampai $30 \%$ maka sistem pengukuran dapat diterima dengan syarat tertentu, sedangkan jika \% variasi repeatability bernilai kurang dari $10 \%$ maka sistem pengukuran dapat diterima. Untuk menghitung \% variasi repeatability yaitu $20 / C g$, dimana $C g$ adalah Capability gauge ditunjukkan pada (4).

$$
C g=\frac{0,2 \times \text { Tolerance }}{6 \times s_{m}}
$$

dimana $s_{m}$ merupakan nilai standar deviasi dari pengukuran.

3) Analyze

Pada fase ini diterapkan alat analisis dalam bentuk peta kendali MEWMA (Multivariate Exponential Weighted Moving Avarage) dan grafik berupa pareto chart dan diagram fishbone. Fase analyze bertujuan untuk mengidentifikasi sumber-sumber dan akar penyebab kecacatan produk, serta membuat prioritas cacat yang memiliki kontribusi dominan terhadap menurunnya kualitas produk [5].

Peta kendali MEWMA merupakan pengembangan dari proses untuk data univariat EWMA yang didefinisikan sebagai berikut [9].

dimana $0<\lambda \leq 1$ dan $i=1,2, \ldots, m$

$$
Z_{i}=\lambda \boldsymbol{X}_{i}+(1-\lambda) Z_{i-1}
$$

Keterangan:

$\boldsymbol{Z}_{i}$ : rata-rata berbobot dari semua rataan sampel sebelumnya, dengan $Z_{0}=0$

$\lambda$ : nilai pembobot, $0<\lambda \leq 1$

$m$ : banyaknya sampel pengamatan yang dilakukan
Titik-titik pengamatan yang diplotkan pada peta kendali MEWMA adalah:

$$
T_{i}^{2}=\mathbf{Z}_{i}^{T} \sum_{Z_{i}}^{-1} \mathbf{Z}_{i-1}
$$

dimana

$$
\boldsymbol{\Sigma}_{\mathbf{Z i}}=\frac{\lambda}{2-\lambda}\left[1-(1-\lambda)^{2 i}\right] \mathbf{\Sigma}
$$

dengan $\boldsymbol{\Sigma}_{\mathbf{Z i}}$ merupakan matriks kovarian dari $\boldsymbol{Z}_{i}$.

Peta kendali MEWMA juga robust terhadap distribusi normal. Proses dikatakan tidak terkendali apabila terdapat nilai $T_{i}>H$ [10], dimana $H$ adalah nilai batas kendali atas.

Pada penelitian ini terdapat 4 karakteristik kualitas. Salah satu metode untuk mengetahui apakah terdapat korelasi antar karakteristik kualitas yaitu dengan menggunakan uji Bartlett. Hipotesisnya sebagai berikut.

$\mathrm{H}_{0}$ : Tidak ada korelasi antar karakteristik kualitas

$\mathrm{H}_{1}$ : Ada korelasi antar karakteristik kualitas

Statistik uji sebagai berikut [11]:

$$
\chi_{\text {hitung }}^{2}=-\left(m-1-\frac{2 p+5}{6}\right) \ln |\mathbf{R}|
$$

Tolak $\mathrm{H}_{0}$ jika $\chi_{\text {hitung }}^{2}>\chi_{\alpha, \frac{p(p-1)}{2}}^{2}$ yang berarti terdapat hubungan antar karakteristik kualitas.

\section{4) Improve}

Pada fase improve ditetapkan suatu rencana tindakan untuk melaksanakan peningkatan kualitas dengan cara membuat tabel FMEA (Failure Mode and Effect Analysis). Digunakan kriteria keparahan (severity), probabilitas kejadian (occurrence), dan pendeteksian (detectability) untuk mendapatkan nilai Risk Priority Number (RPN).

$$
R P N=S \times O \times D
$$

Rentang skor penilaian untuk ketiga kriteria adalah $1,2,3, \ldots, 10$. Nilai 10 disetiap kriteria menunjukkan penyebab potensial sering terjadi, efek yang ditimbulkan besar, sulit dideteksi. Perbaikan proses difokuskan pada nilai RPN terbesar [12]. Pada fase ini juga diimplementasikan saran/rekomendasi yang diberikan peneliti.

\section{5) Control}

Pada fase control dilakukan pengembangan rencana pengendalian dan memperbarui rencana pelatihan serta membuat usulan perubahan Work Order (WO) perusahaan[4].

\section{B. Proses Produksi Deo Go! Potato}

Tahapan proses produksi biskuit Deo Go! Potato ditampilkan pada gambar berikut:

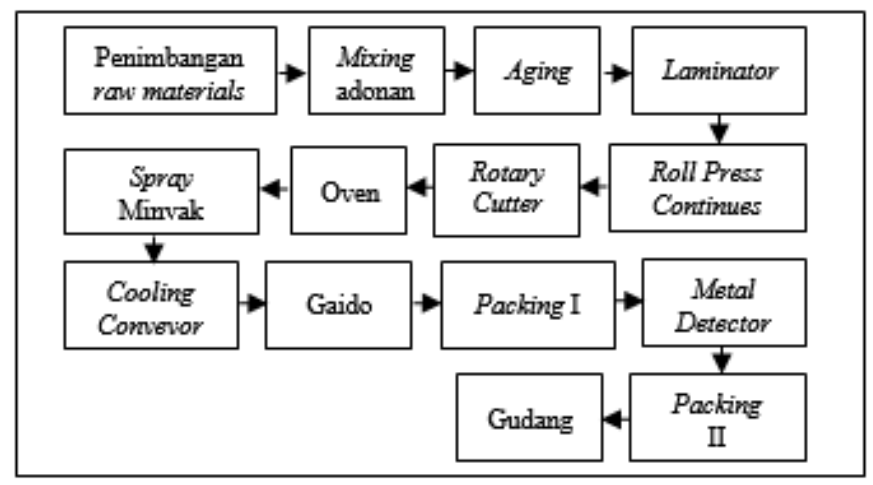

Gambar 1. Diagram Alir Proses Produksi Biskuit Deo Go! Potato. 


\section{METODOLOGI PENELITIAN}

\section{A. Sumber Data}

Data yang digunakan dalam penelitian ini adalah data sekunder yang didapatkan dari bagian quality control (QC) di divisi biskuit PT. Siantar Top, Tbk. Data sekunder yang akan diteliti merupakan data produksi Go! Potato jenis Deo pada bulan Februari hingga Maret 2017.

\section{B. Variabel Penelitian}

Variabel yang digunakan dalam penelitian ini adalah empat karakteristik kualitas biskuit yaitu berat (gr), diameter horizontal $(\mathrm{mm})$, diameter vertikal, dan ketebalan $(\mathrm{mm})$. Struktur data pada karakteristik kualitas dalam penelitian ini yaitu sebagai berikut.

Tabel 1.

Struktur Data Karakteristik Kualitas Deo Go! Potato

\begin{tabular}{cccccc}
\hline \hline \multirow{2}{*}{ Subgrup } & \multicolumn{5}{c}{ Variabel Kualitas } \\
\cline { 2 - 6 } 1 & Pengamatan & $\mathrm{X}_{1}$ & $\mathrm{X}_{2}$ & $\mathrm{X}_{3}$ & $\mathrm{X}_{4}$ \\
& 1 & $\mathrm{X}_{111}$ & $\mathrm{X}_{121}$ & $\mathrm{X}_{131}$ & $\mathrm{X}_{141}$ \\
& 2 & $\mathrm{X}_{112}$ & $\mathrm{X}_{122}$ & $\mathrm{X}_{132}$ & $\mathrm{X}_{142}$ \\
& $\vdots$ & $\vdots$ & $\vdots$ & $\vdots$ & $\vdots$ \\
2 & 1 & $\mathrm{X}_{11 n}$ & $\mathrm{X}_{12 n}$ & $\mathrm{X}_{13 n}$ & $\mathrm{X}_{14 n}$ \\
\hline & 2 & $\mathrm{X}_{212}$ & $\mathrm{X}_{222}$ & $\mathrm{X}_{231}$ & $\mathrm{X}_{241}$ \\
& $\vdots$ & $\vdots$ & $\vdots$ & $\vdots$ & $\vdots$ \\
& $n$ & $\mathrm{X}_{21 n}$ & $\mathrm{X}_{22 n}$ & $\mathrm{X}_{23 n}$ & $\mathrm{X}_{24 n}$ \\
& $\vdots$ & $\vdots$ & $\vdots$ & $\vdots$ & $\vdots$ \\
& 1 & $\mathrm{X}_{m 11}$ & $\mathrm{X}_{m 21}$ & $\mathrm{X}_{m 31}$ & $\mathrm{X}_{m 41}$ \\
& 2 & $\mathrm{X}_{m 12}$ & $\mathrm{X}_{m 22}$ & $\mathrm{X}_{m 32}$ & $\mathrm{X}_{m 42}$ \\
& $\vdots$ & $\vdots$ & $\vdots$ & $\vdots$ & $\vdots$ \\
& $n$ & $\mathrm{X}_{m 1 n}$ & $\mathrm{X}_{m 2 n}$ & $\mathrm{X}_{m 3 n}$ & $\mathrm{X}_{m 4 n}$ \\
\hline \hline
\end{tabular}

Keterangan:

$\mathrm{x}_{1}$ : berat; $\mathrm{x}_{2}$ : diameter horizontal; $\mathrm{x}_{3}:$ diameter vertikal; $\mathrm{x}_{4}$ : ketebalan

$m$ : banyaknya subgrup yang diamati $(m=100)$

$n$ : Ukuran subgrup $(m=9)$

\section{Diagram Alir Penelitian}

Berikut langkah analisis dalam penelitian ini.

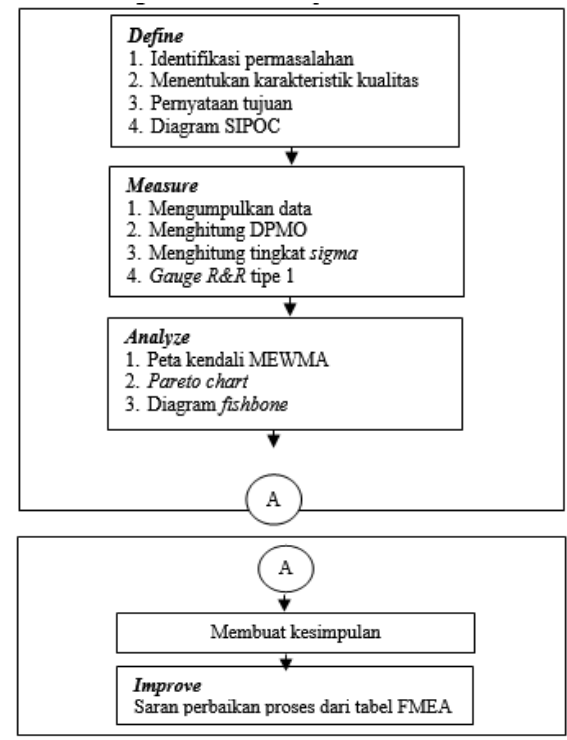

Gambar 2. Diagram alir penelitian.

\section{ANALISIS DAN PEMBAHASAN}

\section{A. Karakteristik Kualitas Produk Deo Go! Potato}

Deskripsi hasil proses produksi Deo Go! Potato pada bulan Februari hingga Maret 2017 yaitu sebagai berikut.

Tabel 2.

Deskripsi Hasil Proses Produksi Deo Go! Potato

\begin{tabular}{lcccccc}
\hline \hline $\begin{array}{c}\text { Karakte- } \\
\text { ristik } \\
\text { Kualitas }\end{array}$ & Spesifikasi & $\begin{array}{c}\text { Rata- } \\
\text { rata }\end{array}$ & Varians & Maks & Min & Cacat \\
\hline $\begin{array}{l}\text { Berat } \\
\text { Diameter }\end{array}$ & $9,5-10,5 \mathrm{gr}$ & 10,026 & 0,0214 & 10,51 & 9,03 & $0,56 \%$ \\
$\begin{array}{l}\text { Horizontal } \\
\text { Diameter }\end{array}$ & $54-56 \mathrm{~mm}$ & 55,685 & 0,0529 & 56,43 & 54,6 & $2 \%$ \\
$\begin{array}{l}\text { Vertikal } \\
\text { Ketebalan }\end{array}$ & $5,56 \mathrm{~mm}$ & 55,399 & 0,0559 & 55,99 & 54,36 & 0 \\
\hline
\end{tabular}

Berdasarkan Tabel 2 dapat diketahui semakin mean proses mendekati batas spesifikasi, maka semakin banyak defect yang dihasilkan. Persentase defect paling besar terindikasi pada karakteristik ketebalan, sedangkan yang paling sedikit pada karakteristik berat. Sementara itu, nilai varians yang diperoleh kecil, artinya data hasil proses produksi semakin seragam atau cenderung mendekati nilai mean.

\section{B. Analisis Six Sigma}

Pada penelitian ini menggunakan pendekatan Six Sigma dengan metodologi DMAIC.

\section{1) Define}

Pada Bab Pendahuluan telah mendefinisikan permasalahan yang terjadi pada proses produksi dan menentukan karakteristik kualitas yang berkaitan. Selanjutnya pada bab ini dilakukan pembuatan pernyataan tujuan (goal statement) yang disajikan pada Tabel 3 berikut.

Tabel 3.

Goal Statement Proyek Six Sigma

\begin{tabular}{|c|c|c|c|}
\hline \multicolumn{4}{|c|}{ Informasi Penelitian dan Tim Peneliti } \\
\hline $\begin{array}{l}\text { Nama } \\
\text { Proyek }\end{array}$ & $\begin{array}{c}\text { Pengendalian dan } \\
\text { Peningkatan Kualitas } \\
\text { Produk Deo Go! Potato } \\
\text { Menggunakan Metode } \\
\text { Six Sigma di PT. Siantar } \\
\text { Top, Tbk } \\
\end{array}$ & $\begin{array}{l}\text { Lokasi } \\
\text { Proyek }\end{array}$ & $\begin{array}{l}\text { Divisi Biskuit } \\
\text { PT. Siantar Top, Tbk }\end{array}$ \\
\hline $\begin{array}{l}\text { Nama } \\
\text { Peneliti }\end{array}$ & Luluk Mukarromah & $\begin{array}{l}\text { Institusi } \\
\text { Peneliti }\end{array}$ & $\begin{array}{l}\text { Jurusan Statistika, } \\
\text { FMIPA, } \\
\text { ITS }\end{array}$ \\
\hline Inspektor & Imron Ashari & $\begin{array}{l}\text { Pembim } \\
\text { bing }\end{array}$ & $\begin{array}{l}\text { Drs. Haryono, MSIE } \\
\text { dan } \\
\text { Diaz Fitra Aksioma, } \\
\text { M.Si }\end{array}$ \\
\hline $\begin{array}{l}\text { Proyek } \\
\text { Mulai }\end{array}$ & 17 Februari 2017 & $\begin{array}{l}\text { Proyek } \\
\text { Berakhir }\end{array}$ & Juni 2017 \\
\hline \multicolumn{4}{|c|}{ Pernyataan Masalah } \\
\hline \multicolumn{4}{|c|}{$\begin{array}{l}\text { Selama bulan Februari hingga Maret 2017, hasil proses produksi yang defect } \\
\text { adalah sebesar 5,45\% atau jika dikonversikan ke dalam level sigma menjadi } \\
3,71 \text { sigma, sehingga terdapat gap sebesar 3,45\% dari target maksimal defect } \\
\text { yang ditetapkan perusahaan yaitu } 1 \% \text { per bulan. }\end{array}$} \\
\hline \multicolumn{4}{|c|}{ Pernyataan Tujuan } \\
\hline \multicolumn{4}{|c|}{$\begin{array}{l}\text { Tujuan proyek ini adalah menghitung tingkat sigma proses produksi biskuit } \\
\text { Deo Go! Potato saat ini, kemudian menentukan faktor-faktor yang } \\
\text { menyebabkan produk tidak sesuai spesifikasi. Setelah itu, proyek ini akan } \\
\text { memberikan saran perbaikan proses kepada PT. Siantar Top, Tbk khususnya } \\
\text { bagian quality control divisi biskuit untuk mengurangi defect dalam proses } \\
\text { supaya dibawah target } 1 \% \text {. } \\
\text { Lingkup Proyek: } \\
\text { Lingkup proyek ini adalah karakteristik kualitas pada proses produksi yang } \\
\text { dilakukan pengukuran yaitu berat, diameter, dan ketebalan biskuit. }\end{array}$} \\
\hline
\end{tabular}


Kegiatan selanjutnya adalah membuat diagram SIPOC dari proses produksi Deo Go! Potato yang disajikan pada Gambar 2. Selain itu, peneliti juga membuat histogram pada Gambar 3 yang bertujuan untuk mengidentifikasi permasalahan yang terjadi pada masing-masing karakteristik kualitas.

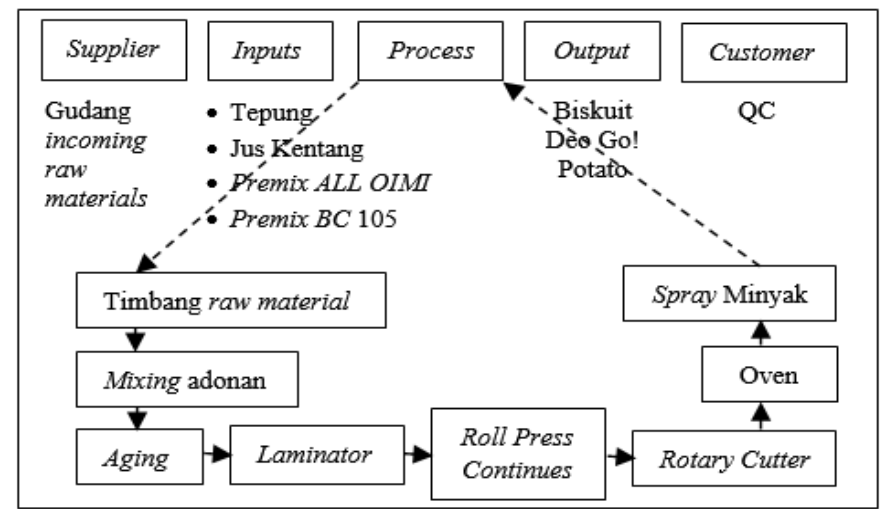

Gambar 2. Diagram SIPOC Proses Produksi Biskuit.

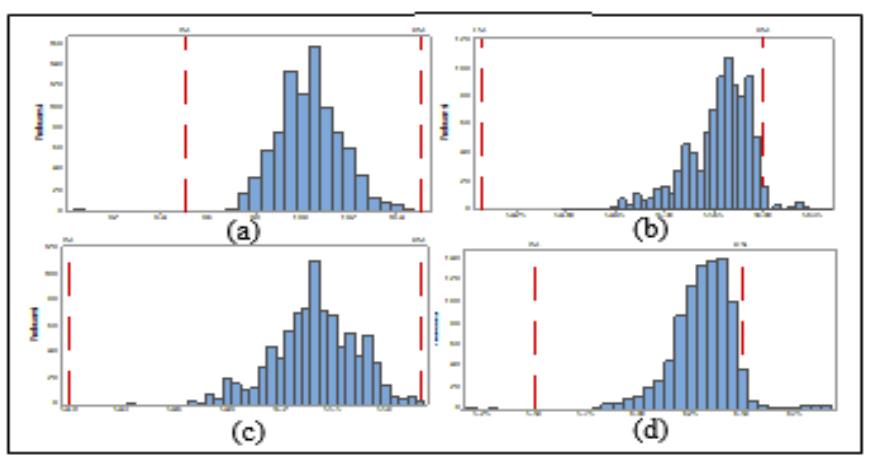

Gambar 3. Histogram (a) Berat, (b) Diameter Horizontal, (c) Diameter Vertikal, (d) Ketebalan.

Berdasarkan Gambar 3 menunjukkan bahwa proses produksi menghasilkan produk yang tidak sesuai spesifikasi (defect).

\section{2) Measure}

Kegiatan pada fase measure yaitu mengukur nilai DPMO untuk mengetahui level sigma saat ini.

Nilai DPMO yang diperoleh dari keseluruhan proses produksi yaitu 13.611, artinya dalam satu juta produk yang dihasilkan terdapat sebanyak 13.611 produk defect. Apabila nilai DPMO ini dikonversikan ke nilai sigma, maka didapatkan bahwa proses produksi Deo Go! Potato berada pada tingkat 3,71 sigma.

Tabel 4.

Analisis Sigma Proses Produksi Deo Go! Potato

\begin{tabular}{lcccc}
\hline \hline $\begin{array}{c}\text { Karakteristik } \\
\text { Kualitas }\end{array}$ & $\begin{array}{c}\text { Jumlah } \\
\text { Unit } \\
\text { Pengamatan }\end{array}$ & $\begin{array}{c}\text { Jumlah } \\
\text { Produk } \\
\text { Cacat }\end{array}$ & DPMO & Sigma \\
\hline Berat $\left(\mathrm{x}_{1}\right)$ & & 5 & 5.556 & 4,04 \\
Diameter & 900 & 18 & 20.000 & 3,55 \\
Horizontal $\left(\mathrm{x}_{2}\right)$ & & 0 & 0 & 0 \\
Diameter & & 26 & 28.889 & 3,40 \\
Vertikal $\left(\mathrm{x}_{3}\right)$ & 900 & 49 & 13.611 & 3,71 \\
\hline Ketebalan $\left(\mathrm{x}_{4}\right)$ & \multicolumn{1}{c}{ Jumlah } & & & \\
\hline \hline
\end{tabular}

Keterangan: tiap unit pengamatan terdiri dari 5 pes biskuit
Pada fase ini juga dilakukan pengujian terhadap kemampuan alat ukur yang digunakan dengan menggunakan Gauge $R \& R$ tipe 1 . Berdasarkan output Gauge $R \& R$ tipe 1 diperoleh nilai persentase variasi (repeatability) sebagai berikut.

Tabel 5

Gauge $R \& R$ Type 1 Pada Karakteristik Kualitas Deo Go! Potato

\begin{tabular}{ccccc}
\hline \hline & \multicolumn{4}{c}{ Karakteristik Kualitas } \\
\cline { 2 - 5 }$\%$ Var (Repeatability) & $\mathrm{x}_{1}$ & $\mathrm{x}_{2}$ & $\mathrm{x}_{3}$ & $\mathrm{x}_{4}$ \\
\hline \hline
\end{tabular}

Nilai \%Var (Repeatability) dari semua variabel karakteristik kualitas berada diantara $10 \%$ dan 30\%. Menurut AIAG, apabila nilai \%Var (Repeatability) diantara 10\% dan 30\% maka sistem pengukuran yang digunakan bisa diterima (acceptable) dengan syarat tertentu. Dengan demikian dapat disimpulkan bahwa alat ukur yang digunakan pada proses produksi Deo Go! Potato sudah baik.

3) Analyze

Kegiatan pada fase analyze diawali dengan membuat peta kendali MEWMA. Sebelumnya dilakukan pengujian korelasi menggunaka uji Bartlett. Berdasarkan perhitungan diperoleh nilai $\chi_{\text {hitung }}^{2}$ sebesar 86,659 dengan $p$-value sebesar 0,000. Karena nilai $p$-value $<\alpha(0,05)$ maka $\mathrm{H}_{0}$ ditolak. Selain itu diperoleh hasil nilai $\chi_{\text {hitung }}^{2}$ lebih besar dibandingkan nilai $\chi_{\text {tabel. }}^{2}$. Nilai $\chi_{\text {tabel }}^{2}$ dengan $d f=6$ adalah 12,59. Dengan demikian dapat disimpulkan bahwa terdapat hubungan antar karakteristik kualitas biskuit Deo Go! Potato yaitu berat, diameter horizontal, diameter vertikal, dan ketebalan.

Setelah asumsi korelasi pada karakteristik kualitas terpenuhi maka dapat dilakukan pengendalian mean proses dengan peta kendali MEWMA. Diketahui pergeseran rata-rata proses produksi pada bulan Februari hingga Maret 2017 sebesar 1,71727. Pembobot yang digunakan pada peta kendali MEWMA yaitu antara 0,05 dan 0,1 hingga 0,8 (dengan selisih 0,1) sesuai dengan penelitian Prabhu \& Runger (1997) dalam [9]. Hasil pengamatan dari 9 peta kendali MEWMA dengan pembobot yang berbeda-beda ditampilkan pada Tabel 6 . Pemilihan pembobot terbaik dengan mencari selisih minimum dari titik pengamatan maksimal dan batas kendali atas $(H)$.

Tabel 6.

Selisih Titik Pengamatan Maksimal dengan $H$

\begin{tabular}{cccc}
\hline \hline$\lambda$ & Titik Pengamatan Maksimal & $H$ & Selisih \\
\hline 0,05 & 16,72 & 8,75 & 7,97 \\
0,1 & 21,03 & 10,45 & 10,58 \\
0,2 & 20,98 & 11,77 & 9,21 \\
0,3 & 21,50 & 12,34 & 9,16 \\
0,4 & 19,70 & 12,64 & 7,06 \\
0,5 & 18,43 & 12,81 & 5,62 \\
0,6 & 19,30 & 12,91 & 6,39 \\
0,7 & 19,68 & 12,97 & 6,71 \\
0,8 & 19,65 & 13,01 & 6,64 \\
\hline \hline
\end{tabular}

Berdasarkan Tabel 6 nilai pembobot yang optimal untuk peta kendali MEWMA adalah 0,5 karena memiliki selisih yang paling kecil yaitu 5,62. Hasil peta kendali MEWMA dengan pembobot 0,5 tertera pada Gambar 4 . 


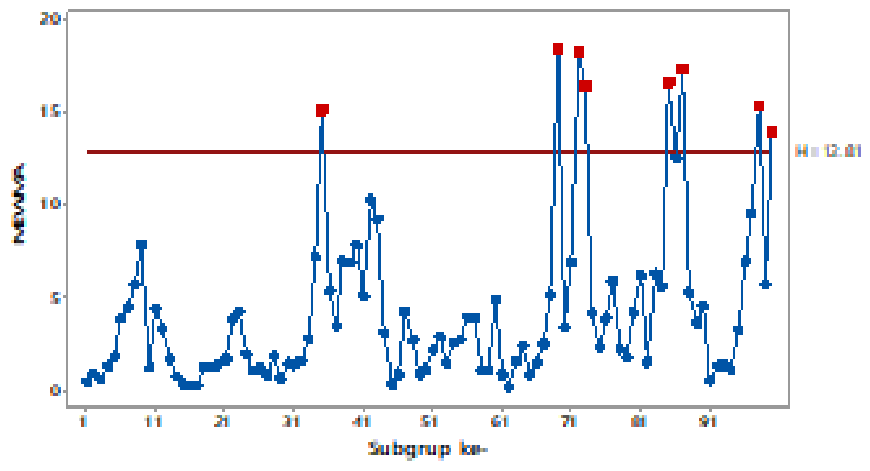

Gambar 4. Peta Kendali MEWMA dengan pembobot 0,5.

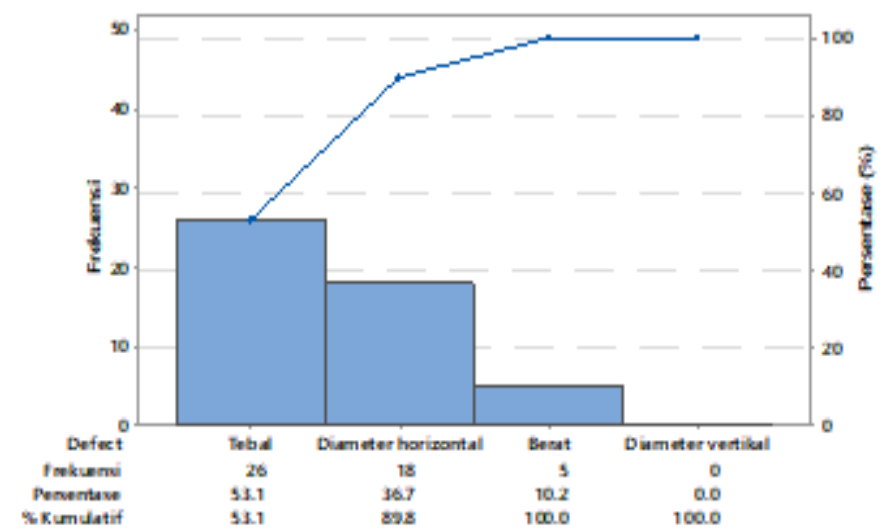

Gambar 5. Pareto Chart Jenis Defect pada Proses Produksi Deo Go! Potato.

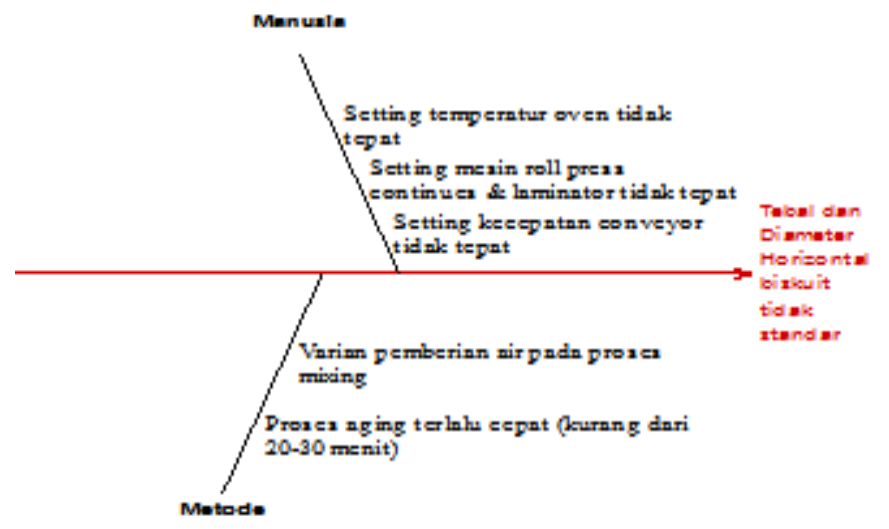

Gambar 6. Diagram Fishbone Penyebab Tebal dan Diameter Horizontal Biskuit Tidak Standar.

Hasil pengontrolan mean proses menunjukkan rata-rata proses produksi Deo Go! Potato tidak terkendali secara statistik. Sebanyak 7 titik pengamatan berada di luar batas kendali atas $(H)$ yaitu pengamatan ke $35,69,72,73,85,87$, 98 , dan 100. Subgrup yang keluar batas kendali tersebut terjadi pada tanggal 22, 27, 28 Februari dan 1 Maret 2017. Titik-titik subgrup out of control tersebut harus dicari penyebabnya terlebih dahulu sebelum melakukan improvement.

Pada fase analyze juga dibuat pareto chart dari jenis defect hasil proses produksi Deo Go! Potato yang disajikan pada Gambar 5 berikut.

Gambar 6 menjelaskan penyebab tebal biskuit tidak standar berdasarkan hasil brainstorming dengan kepala bagian quality
Tabel 7.

FMEA untuk Jenis Defect Tebal Tidak Standar

\begin{tabular}{|c|c|c|c|c|c|c|c|c|}
\hline \multirow{2}{*}{$\begin{array}{l}\text { Karak- } \\
\text { teristik } \\
\text { Kuali- } \\
\text { tas } \\
\end{array}$} & \multirow{2}{*}{$\begin{array}{c}\text { Efek } \\
\text { Kegagalan } \\
\text { Potensial }\end{array}$} & \multirow{2}{*}{$\begin{array}{c}\text { Modus } \\
\text { Kegagalan } \\
\text { Potensial }\end{array}$} & \multirow[b]{2}{*}{$\begin{array}{l}\text { Penyebab } \\
\text { Potensial }\end{array}$} & \multicolumn{3}{|c|}{ Nilai } & \multirow[b]{2}{*}{ RPN } & \multirow[b]{2}{*}{$\begin{array}{l}\text { Rekome } \\
\text { n-dasi }\end{array}$} \\
\hline & & & & $S$ & $O$ & $D$ & & \\
\hline \multirow[t]{2}{*}{ : } & \multirow[b]{2}{*}{$\begin{array}{l}\text { Tebal } \\
\text { biskuit } \\
\text { over/ } \\
\text { kurang } \\
\text { standar }\end{array}$} & $\begin{array}{l}\text { Biskuit } \\
\text { terlalu } \\
\text { mengem } \\
\text {-bang }\end{array}$ & $\begin{array}{l}\text { Setting } \\
\text { temperatur } \\
\text { oven pada } \\
\text { zona I, II, } \\
\text { III, dan IV } \\
\text { tidak tepat }\end{array}$ & 7 & 8 & 5 & 280 & $\begin{array}{l}\text { Pemberi } \\
\text { an } \\
\text { latihan } \\
\text { kepada } \\
\text { operator } \\
\text { cara } \\
\text { mengop } \\
\text { erasi- } \\
\text { kan } \\
\text { oven }\end{array}$ \\
\hline & & $\begin{array}{l}\text { Ketebal- } \\
\text { an sheet } \\
\text { adonan } \\
\text { tidak } \\
\text { merata }\end{array}$ & $\begin{array}{l}\text { Setting } \\
\text { mesin roll } \\
\text { press } \\
\text { continues } \\
\text { dan } \\
\text { laminator } \\
\text { tidak tepat }\end{array}$ & 3 & 3 & 3 & 27 & $\begin{array}{l}\text { Pemberi } \\
\text { an } \\
\text { latihan } \\
\text { kepada } \\
\text { operator } \\
\text { cara } \\
\text { mengop } \\
\text { e- } \\
\text { rasikan } \\
\text { mesin } \\
\text { roll } \\
\text { press } \\
\text { continue } \\
s \text { dan } \\
\text { laminat } \\
\text { or }\end{array}$ \\
\hline & \multirow{3}{*}{$\begin{array}{l}\text { Diameter } \\
\text { horizon- } \\
\text { tal } \\
\text { biskuit } \\
\text { over/ } \\
\text { kurang } \\
\text { standar }\end{array}$} & \multirow[b]{2}{*}{$\begin{array}{l}\text { Adonan } \\
\text { tidak } \\
\text { stabil }\end{array}$} & $\begin{array}{l}\text { Proses } \\
\text { aging } \\
\text { terlalu } \\
\text { cepat } \\
\text { (kurang } \\
\text { dari 20-30 } \\
\text { menit) } \\
\end{array}$ & 3 & 2 & 3 & 18 & $\begin{array}{l}\text { Penggun } \\
\text { a-an alat } \\
\text { bantu } \\
\text { berupa } \\
\text { timer }\end{array}$ \\
\hline & & & $\begin{array}{l}\text { Varian } \\
\text { pemberian } \\
\text { air }\end{array}$ & 4 & 2 & 5 & 40 & $\begin{array}{l}\text { Membu } \\
\text { at } \\
\text { intruksi } \\
\text { kerja } \\
\text { mengen } \\
\text { ai } \\
\text { pemakai } \\
\text { an air } \\
\text { sesuai } \\
\text { kadar } \\
\text { air } \\
\text { adonan }\end{array}$ \\
\hline & & $\begin{array}{l}\text { Diameter } \\
\text { tertarik } \\
\text { dan } \\
\text { melebar }\end{array}$ & $\begin{array}{l}\text { Pergantian } \\
\text { antara belt } \\
\text { conveyor } \\
\text { dan net } \\
\text { oven }\end{array}$ & 2 & 2 & 2 & 8 & $\begin{array}{l}\text { Pemberi } \\
\text { an } \\
\text { latihan } \\
\text { kepada } \\
\text { operator } \\
\text { cara } \\
\text { men- } \\
\text { setting } \\
\text { kecepata } \\
\text { n mesin }\end{array}$ \\
\hline
\end{tabular}

control divisi biskuit di PT. Siantar Top, Tbk. Dari beberapa penyebab didapatkan penyebab utamanya adalah faktor manusia, yaitu operatur yang kurang teliti dalam mengatur setting temperatur oven.

Sebagian besar defect pada proses produksi disebabkan oleh jenis defect berupa tebal biskuit tidak standar yaitu sebesar $45,7 \%$. Jenis defect diameter horizontal biskuit tidak standar merupakan jenis defect terbanyak kedua yaitu $36,7 \%$. Selanjutnya, perbaikan proses lebih memfokuskan pada jenis defect terbanyak mencapai $80 \%$ yaitu tebal dan diameter horizontal tidak standar untuk dianalisis akar permasalahannya dengan diagram fishbone. 


\section{4) Improve}

Pada fase improve dibuat tabel FMEA. Pemberian skor $S$, $O$, dan $D$ pada tabel FMEA dilakukan oleh kepala bagian quality control. Dari tabel FMEA diketahui nilai RPN terbesar yang menjadi penyebab potensial tebal dan diameter horizontal biskuit tidak standar ialah setting temperatur oven pada zona I, II, III, dan IV tidak tepat dan varian pemberian air saat mixing adonan. Berikut ini merupakan usulan-usulan perbaikan yang diajukan untuk mengurangi jumlah defect pada proses produksi.

\section{KESIMPULAN}

Level sigma proses produksi biskuit Deo Go! Potato pada bulan Februari hingga Maret 2017 adalah 3,71 sigma dengan nilai DPMO sebesar 13.611. Tebal dan diameter horizontal tidak standar merupakan jenis defect terbanyak yaitu mencapai $89,8 \%$. Faktor-faktor yang paling berpengaruh terhadap jenis defect ini adalah faktor manusia dan metode. Saran yang diberikan pada pihak perusahaan untuk perbaikan proses produksi adalah memberikan pelatihan kepada karyawan cara mengoperasikan oven, membuat intruksi kerja terkait pemakaian air pada proses mixing adonan, memberikan latihan cara mengoperasikan mesin laminator dan roll press continues. Selain itu, perlu digunakannya alat bantu berupa timer pada proses aging dan pemberian latihan cara mensetting kecepatan mesin conveyor.

Sebaiknya pengukuran karakteristik kualitas dilakukan oleh 2 operator atau lebih sehingga dapat dilakukan pengukuran Gauge Reproducibility. Untuk penelitian selanjutnya disararankan agar membuat penjadwalan yang baik dan memperhatikan waktu penelitian supaya siklus DMAIC dapat dilakukan secara keseluruhan.

\section{UCAPAN TERIMA KASIH}

Penulis L.M. mengucapkan terima kasih kepada PT. Siantar Top, Tbk atas kesediannya membantu penelitian tentang Six Sigma ini.

\section{DAFTAR PUSTAKA}

[1] P. O. Hapsari, "Penerapan Diagram Kontrol MEWMA dan MEWMV Pada Proses Produksi Coca-Cola 1,5 L PT. Coca-Cola Bottling Indonesia Jawa Timur," 2009.

[2] J. Susetyo, Winarni, and C. Hartanto, "Aplikasi Six Sigma DMAIC dan Kaizen Sebagai Metode Pengendalian dan Perbaikan Kualitas Produk," J. Teknol., vol. 4, pp. 78-87, 2011.

[3] H. P. Rakasiwi, "Analisis Six Sigma Pada Produk Casing Pompa Sebagai Metode Perbaikan Kualitas (Studi Kasus: PT. Zenith Allmart Precisindo)," Surabaya, 2014.

[4] D. H. Stamatis, Six Sigma and Beyond: Foundations of Excellent Performance. Florida: CRC Press, 2001.

[5] P. Rumana and D. A. Desai, "Review Paper: Quality Improvement through Six Sigma DMAIC Methodology," Int. J. Eng. Sci. Res. Technol., vol. 3, pp. 169-175, 2014.

[6] J. R. Evans and W. M. Lindsay, Pengantar Six Sigma: An Introduction to Six Sigma \& Process Improvement. Jakarta: Salemba Empat, 2007.

[7] S. Hosea and D. Anne, "Upaya Peningkatan Kualitas A Keramik Murano Pada PT Y Dengan Filosofi Six Sigma,” J. Titra, vol. 1, pp. 27-32, 2013.

[8] Chrysler Motors, GM Company, and Ford Motors Company, "Measurement Systems Analysis Reference Manual," USA, 2010.

[9] D. C. Montgomery, Introduction to Statistical Quality Control, 7th ed. John Wiley and Sons, Inc, 2012.

[10]A. Arinda, Mustafid, and M. A. Mukid, "Penerapan Diagram Kontrol Multivariate Exponentially Weighted Moving Avarage (MEWMA) Pada Pengendalian Karakteristik Kualitas Air," Gaussian, vol. 5, pp. 31-40, 2016.

[11]D. Morisson, Multivariate Statistical Methods. USA: The Wharton School University of Pennsylvania, 2005.

[12]D. H. Stamatis, Six Sigma and Beyond: Design for Six Sigma, 6th ed. Florida: : CRC Press, 2002. 